DOI: http://dx.doi.org/10.18203/2320-1770.ijrcog20194910

\title{
A rare case of steroid cell tumor of ovary: case report
}

\author{
Sharanya*, Monalisa Peter \\ Department of Obstetrics and Gynecology, St. Philomena's Hospital, Bangalore, Karnataka, India
}

Received: 24 July 2019

Revised: 29 September 2019

Accepted: 05 October 2019

\section{*Correspondence:}

Dr. Sharanya,

E-mail: shrny.7@gmail.com

Copyright: $\odot$ the author(s), publisher and licensee Medip Academy. This is an open-access article distributed under the terms of the Creative Commons Attribution Non-Commercial License, which permits unrestricted non-commercial use, distribution, and reproduction in any medium, provided the original work is properly cited.

\begin{abstract}
Steroid cell tumors of the ovary account for less than $0.1 \%$ of all ovarian tumors. These tumors may present at any age with presentations related to the hormonal activity and virilizing properties of tumor. A 61-year-old postmenopausal women presented with complaints of postmenopausal bleeding for 15 days. Parity score of P3L3, not tubectomised. Menopaused 16 years back. History of weight loss noted. She is a known case of diabetes mellitus for 6 years not on any treatment and a known case of depressive disorder for 35 years on treatment on trihexphenidyl lurasidone. Had undergone sigmoid colon polyp removal in June 2018. On examination, P/A- mild gaseous distension $(+)$. P/S- cervix flushed with vagina, pulled up cervix. P/V- uterus size and position couldn't be made out, anterior fornix fullness (+). Ultrasonography showed bulky uterus with fibroid $4 \mathrm{x} 4 \mathrm{~cm}$, endometrial thickness- $9 \mathrm{~mm}$ ? Krukenberg tumor and posterior mediastinal lymph nodes. Patient underwent Total abdominal hysterectomy with bilateral salpingo-oophorectomy with frozen section on 01/07/19. Frozen section: 1. Ovaries: right ovary fibrothecoma, left ovary- simple cyst. 2. Uterus- endometrial hyperplasia with atypia. 3. Myometrium- leiomyoma and adenomyosis. Postoperative period was uneventful. On microscopic examination, impression: right ovary- steroid cell tumor, uterus-endometrial hyperplasia with cytological atypia. Ovarian steroid cell tumors are grouped under sex chord stromal tumors and are usually benign, unilateral and characterized by a steroid cell proliferation. Steroid cell tumors are associated with androgenic changes with variable frequency, ranging from $12 \%$ to over $50 \%$ respectively. The primary treatment is surgical extirpation of the primary lesion and there are no reports of effective radiation or chemotherapy. In a young patient with stage IA disease, a unilateral salpingo oophorectomy is adequate.
\end{abstract}

Keywords: Endometrial hyperplasia, Krukenberg tumor, Postmenopausal bleeding, Sex cord stromal tumor, Sigmoid colon polyp removal, Steroid cell tumor

\section{INTRODUCTION}

Steroid cell tumours of the ovary account for less than $0.1 \%$ of all ovarian tumours. ${ }^{1}$ These tumours may present at any age with presentations related to the hormonal activity and virilizing properties of tumours. Ovarian steroid cell tumours, not otherwise specified (NOS), are rare sex cord-stromal tumours of the ovary with malignant potential, accounting for less than $0.1 \%$ of all ovarian tumours. $^{2}$ These tumours should be considered a cause of isosexual precocious puberty in children and virilisation in adults, such as hirsutism, temporal balding, and amenorrhea. ${ }^{3}$ In literature only a few cases of steroid cell tumours, NOS, have been described. ${ }^{4}$ Most of the reported cases only described one benign case.

\section{CASE REPORT}

A 61 years old postmenopausal female presented to the department of obstetrics and gynaecology, St Philomena 
Hospital, Bangalore on 20/05/19 with complaints of postmenopausal bleeding 1st episode for 15 days. History of weight loss noted. Parity score P3L3 with last child's age 27 years and not tubectomised. Menopaused 16 years, past cycles- regular. She is a known case of diabetes mellitus for 6 years not on treatment and a known case of depressive disorder for 35 years on treatment - trihexphenidyl lurasidone. Had undergone sigmoid colon polyp removal in June 2018. On examination, P/A- mild gaseous distension (+). P/Scervix flushed with vagina, pulled up cervix. P/V- Uterus size couldn't be made out, anterior fornix fullness $(+)$. Ultrasonography showed fibroid $4 \times 4 \mathrm{~cm}$, E.T. $-9 \mathrm{~mm}$ ? Krukenberg tumours. CT abdomen showing 6.7 x $7.7 \mathrm{~cm}$ fibroid, B/L ovaries-15 $\mathrm{mm}$ cystic lesion in the right ovary? colonic neoplasm;/? krukenberg tumour. All other investigations within normal limits.

Patient underwent total abdominal hysterectomy with bilateral salpingo-oophorectomy with frozen section on 19/07/18. Intraoperative findings: uterus enlarged to 8-10 weeks size, anterior wall intramural fibroid of $4 \times 5 \mathrm{~cm}$, $\mathrm{B} / \mathrm{L}$ fallopian tubes enlarged, $\mathrm{B} / \mathrm{L}$ ovaries: enlarged and bulky.

\section{Frozen section}

- Ovaries: right ovary - fibrothecoma, left ovarysimple cyst

- Uterus - endometrial hyperplasia with atypia

- Myometrium - leiomyoma.

Postoperative period uneventful. On POD-8 suture removal done and wound was healthy.

\section{Microscopic observation}

- Section of uterine wall reveal thickened endometrium

- Section of fallopian tube shows thickened plicae

- Ovarian section shows cyst of ovarian rete

- Section of ovary shows non-capsulated nodular lesion (Figure 1 and 2).

- Impression: right ovary - steroid cell tumour, uterusendometrial hyperplasia with atypia.

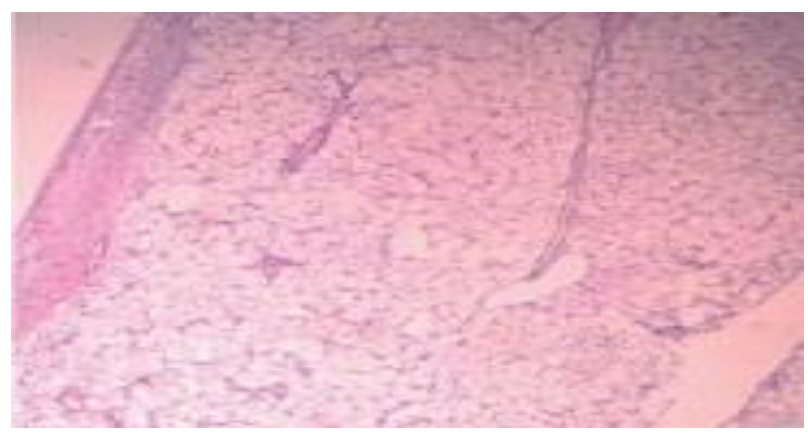

Figurer 1: Microscopic appearance of right ovarywell circumscribed tumor with scanty stroma.

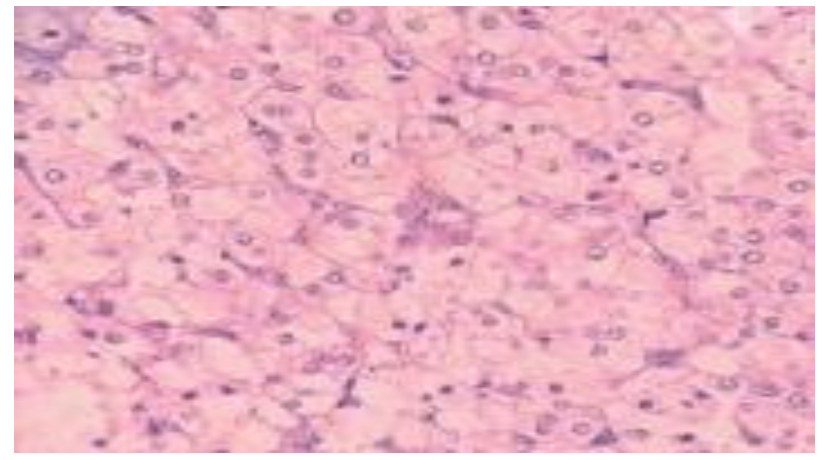

Figure 2: Microscopic appearance of right ovarypolygonal tumor cells with atypia.

\section{DISCUSSION}

Ovarian steroid cell tumours are grouped under sex chord stromal tumours and are usually benign, unilateral and characterized by a steroid cell proliferation. ${ }^{5,6}$ Steroid cell tumours are associated with androgenic changes with variable frequency, ranging from $12 \%$ to over $50 \%$ respectively.,8 The primary treatment is surgical extirpation of the primary lesion and there are no reports of effective radiation or chemotherapy. ${ }^{9-11}$ In a young patient with stage IA disease, a unilateral salpingo oophorectomy is adequate.

The incidence of steroid cell tumours, NOS is highest in women of child bearing age group, particularly during the third and fourth decades, but in rare cases postmenopausal women or children may also have this tumour. Androgenic manifestations are common in these tumours as they secrete hormones like androstenedione, $\alpha$-hydroxyprogesterone, and testosterone. ${ }^{12-14}$

These tumours are known to produce symptoms of virilisation particularly hirsutism. So, in cases where there is unexplained hirsutism, ovarian and adrenal tumour association should be ruled out as there may be occult malignancies. ${ }^{15}$ However, there may be atypical presentations of these tumours also when they do not show any symptoms of virilisation. In these cases, the diagnosis is usually made postoperatively on finding a tumour in ovary. ${ }^{16}$

These tumours have been divided into three subtypes according to their cells of origin: stromal luteoma, leydig cell tumour and steroid cell tumour, not otherwise specified (NOS). Of these subtypes, the steroid cell tumours, NOS account for about $56 \%$ of steroid cell tumours. ${ }^{17}$

A majority of steroid cell tumour NOS are unilateral and well circumscribed. The size varies from 1.2 to $45 \mathrm{~cm}$. Grossly these tumours are commonly solid; however, a combination of solid and cystic form or predominantly cystic form may also be seen. The color of the cut surface may range from yellow to orange to red or brown 
depending upon the lipid content. Area of haemorrhage and necrosis may also be seen. ${ }^{18}$ The tumour in our case was completely solid with no cystic area. The cut surface was typically yellow and lobulated.

Steroid cell tumour, NOS should be differentiated from other two entities in the category of steroid cell tumours including stromal luteoma and leydig cell tumour. Stromal leutoma is usually located in the ovarian stroma. It frequently occurs in association with stromal hyperthecosis. Another feature which can help in diagnosing this tumour is presence of degenerative pseudo vascular spaces containing red blood cells. ${ }^{19}$ On the other hand, leydig cell tumour is usually present in hilar location. The tumour cells show cytoplasmic reinke crystals and it is commonly associated with leydig cell hyperplasia. $^{20}$ Although pregnancy luteoma may sometimes resemble steroid cell tumour microscopically, however it is commonly multifocal and occurs bilaterally in approximately one-third of patients. It usually regresses after pregnancy. ${ }^{21}$ In our case, there was no feature like stromal hyperthecosis, pseudovascular spaces or reinke crystals to suggest the possibility of stromal luteoma and leydig cell tumour.

A clinicopathological correlation is very important in these tumours as the benign looking tumours on histomorphology can behave in a clinical malignant manner. ${ }^{22}$ As far as immunohistochemical markers are concerned, inhibin is quite useful in differentiating this tumour from other non sex cord tumours. ${ }^{23}$

The treatment of these tumours should be based on the histological picture, surgical staging and patient's desire to preserve fertility. ${ }^{24}$ In young patient who want to preserve their fertility, unilateral salpingo-oophorectomy is the preferred method of treatment. ${ }^{25}$

\section{CONCLUSION}

Steroid cell tumors-NOS are very rare ovarian sex cord stromal tumors which are usually associated with various symptoms such as pain in the abdomen, hirsuitism, and irregular menstrual cycles. In postmenopausal women who are eligible for surgery, a diagnostic and therapeutic bilateral salpingo-oophorectomy is a safe option. Along with clinical correlation, histopathology is the gold standard which can confirm the diagnosis in most of the cases.

Funding: No funding sources Conflict of interest: None declared

Ethical approval: Not required

\section{REFERENCES}

1. Young RH, Shully RE. Steroid cell tumours of the ovary. In: Fox H, Wells M, editors. Obstetric and Gynecological Pathology. Spain: Churchill Livingstone; 2003:845-856.
2. Zhang X, Lu B. Ovarian steroid cell tumour, not otherwise specified (NOS): an unusual case with myelolipoma. Int J Gynecol Pathol. 2011;30:460-5.

3. Lee SH, Kang MS, Lee GS, Chung WY. Refractory hypertension and isosexual pseudoprecocious puberty associated with renin-secreting ovarian steroid cell tumour in a girl. J Korean Med Sci. 2011;26:836-8.

4. Sawathiparnich P, Sitthinamsuwan P, Sanpakit K, Laohapensang M, Chuangsuwanich T. Cushing's syndrome caused by an ACTH-producing ovarian steroid cell tumour, NOS, in a prepubertal girl. Endocrine. 2009;35:132-5.

5. Liu AX, Sun J, Shao WQ, Jin HM, Song WQ. Steroid cell tumours, not otherwise specified (NOS), in an accessory ovary: a case report and literature review. Gynecol Oncol. 2005;97:260-2.

6. Deavers MT, Malpica A, Ordonez NG, Silva EG. Ovarian steroid cell tumours: an immunohistochemical study including a comparison of calretinin with inhibin. Int $\mathbf{J}$ Gynecol Pathol. 2003;22:162-7.

7. Flynn A, Ravindranath S. Steroid cell tumour, NOS, of ovary. Indian J Pathol Microbiol. 2008;51:461.

8. Kim YT, Kim SW, Yoon BS, Kim SH, Kim JH, Kim JW, et al. An ovarian steroid cell tumour causing virilization and massive ascites. Yonsei Med J. 2007;48:142-6.

9. Bas F, Saka N, Darendeliler F, Tuzlali S, Ilhan R, Bundak R, et al. Bilateral ovarian steroid cell tumour in congenital adrenal hyperplasia due to classic 11 beta-hydroxylase deficiency. J Pediatr Endocrinol Metab. 2000;13:663-7.

10. Faraj G, Di Gregorio S, Misiunas A, Faure EN, Villabrile P, Stringa I, et al. Virilizing ovarian tumour of cell tumour type not otherwise specified: a case report. Gynecol Endocrinol. 1998;12:347-52.

11. Scully RE, Young RH, Clement PB. Steroid cell tumours. In: Tumours of the Ovary, Mal developed Gonads, Fallopian Tube, and Broad Ligament. Washington, DC: Armed Forces Institute of Pathology; 1996:227-238.

12. Karlan BY, Markman MA, Eifel PJ. Sex cord stromal tumours. In: DeVita VT Jr, Hellman S, Rosenberg SA, editors. Cancer: Principles and Practice of Oncology. Philadelphia: Lippincott Williams and Wilkinson; 2005:1392-1393.

13. Outwater EK, Wagner BJ, Mannion C, McLarney JK, Kim B. Sex cord-stromal and steroid cell tumours of the ovary. Radiograph. 1998;18(6):152346.

14. Cserepes E, Szucs N, Patkos P, Csapo Z, Molnar F, Toth $\mathrm{M}$, et al. Ovarian steroid cell tumour and a contralateral ovarian thecoma in a postmenopausal woman with severe hyperandrogenism. Gynecol. Endocrinol. 2002;16(3):213-6.

15. Dinc G, Saygin I, Kart C, Mungan S, Guven S, Guven E. A rare case of postmenopausal severe virilization: ovarian steroid cell tumour, not 
otherwise specified. J Cases Obstet Gynecol. 2016;3(1):19-21.

16. Rubido Valle CD, Fuente de la JLC, Martinez CS, Calvo LN, Escarda MR. Ovarian steroid cell tumour associated to endometrial hyperplasia and presenting as postmenopausal vaginal bleeding. Gynecol Obstet (Sunnyvale). 2015;5(9):316.

17. Baloglu A, Bezircioglu I, Cetinkaya B, Karci L, Bicer M. Development of secondary ovarian lesions after hysterectomy without oophorectomy versus unilateral oophorectomy for benign conditions: a retrospective analysis of patients during a nine-year period of observation. Clin Exp Obstet Gynecol. 2010;37:299-302.

18. Hayes MC, Scully RE. Ovarian steroid cell tumours (not otherwise specified): A clinic-pathological analysis of 63 cases. Am J Surg Pathol. 1987;11(11):835-45.

19. Scully RE. Stromal luteoma of the ovary. A distinctive type of lipoid-cell tumour. Cancer. 1964;17:769-78.

20. Paraskevas M, Scully RE. Hiluscell tumour of the ovary. A clinico-pathological analysis of 12 Reinke crystal-positive and nine crystal- negative cases. Int J Gynecol Pathol. 1989;8(4):299-310.
21. Clement PB. Tumour-like lesions of the ovary associated with pregnancy. Int $\mathrm{J}$ Gynecol Pathol. 1993;12(2):108-15.

22. Mehdi G, Ansari HA, Sherwani RK, Rahman K, Akhtar N. Ovarian steroid cell tumour: correlation of histopathology with clinico-pathologic features. Pathol Res Int. 2011;2011:987895.

23. Rabban JT, Zaloudek CJ. A practical approach to immune-histochemical diagnosis of ovarian germ cell tumours and sex cord-stromal tumours. Histopathol. 2013;62:71-88.

24. Jiang W, Tao X, Fang F, Zhang S, Xu C. Benign and malignant ovarian steroid cell tumours, not otherwise specified: case studies, comparison, and review of the literature. J Ovarian Res. 2013;6:53.

25. Swain J, Sharma S, Prakash V, Agrawal NK, Singh SK. Steroid cell tumour: a rare cause of hirsutism in a female. Endocrinol, Diabet Metabol Case Rep. 2013;2013:130030.

Cite this article as: Sharanya, Peter M. A rare case of steroid cell tumor of ovary: case report. Int J Reprod Contracept Obstet Gynecol 2019;8:4622-5. 